\title{
Ellipsis
}

2014

\section{A Compendium of Ghosts}

Jennifer Hanks

Follow this and additional works at: https://scholarworks.uno.edu/ellipsis

Part of the Poetry Commons

\section{Recommended Citation}

Hanks, Jennifer (2014) "A Compendium of Ghosts," Ellipsis: Vol. 41 , Article 8.

DOI: https://doi.org/10.46428/ejail.41.08

Available at: https://scholarworks.uno.edu/ellipsis/vol41/iss1/8

This Poetry is brought to you for free and open access by the Department of English and Foreign Languages at ScholarWorks@UNO. It has been accepted for inclusion in Ellipsis by an authorized editor of ScholarWorks@UNO. For more information, please contact scholarworks@uno.edu. 


\section{A Compendium of Ghosts}

Jennifer Hanks

Andrea Saunders Gereighty / Academy of American Poets Award Winner

1.

When I get worried I make a ring of vines around our couch, and smaller ones for our wrists. I lift your shirt and tie one around your ribs, but not right under your breasts.

Sometimes I wish for them to stay, flattening themselves into pendants and shards of glass that might get in my feet.

\section{2.}

There is hissing in the house tonight. It is like the noise you make when I try to get out of the bed before you, but you aren't here.

3.

Once a ghost talked to me through you. More often they are subtle, but I keep expecting to get into bed and find it already occupied, lay down and feel like I am sinking into the deep part of a pool, the part where you know every shadow is a shark with teeth it can afford to lose in your skin.

4.

Closet ghosts, ghosts that float out of your tights when you shake them out. A ghost that talks only to cats, exerting its transparent, breathless vocal chords to produce a convincing meow.

\section{5 .}

I wish I could see something else in the dark, the way I used to think of an assembly line of girls going down on me one after another while I sat in an armchair. Tonight this is too sad as if the girls and you, watching diligently and moving them along, would all be disappointed.

Why can't I hold the ghosts of what I no longer look like at bay? When I am trying to break your bed I feel them behind me, their long hair brushing against my back. 
6.

The ghosts of big stars. The ones I point out to you when we are in a rare place where you can see them. The stars I think about when I'm listening to a band that claims the moon is coming for us and I think, we will not be anonymous for ever.

I want us to be visible from space after we die. I want our ghosts upright as wooden arrows, marking the places where our blood stopped running. Our ghosts should be solid as skeletons, made of opal bones that capture light. 